\title{
Changes in the proximate and fatty acid composition in carp meat during the semi intensive farming
}

\author{
Trbović Dejanal, Marković Zoran ${ }^{2}$, Petronijević Radivoj ${ }^{1}$, Milijašević Milan ${ }^{1}$, Spirić Danka ${ }^{l}$, \\ Vranić Danijelal, Spirić Aurelijal
}

$S$ u $m$ m a ry: The aim of this study was to examine and evaluate the proximate composition and fatty acid profiles of carp (Cyprinus carpio) during rearing in the semi-intensive farming conditions, supplementary fed extruded feed. Carp at the age of two years was submitted to trials, from spring to autumn, at the fish farm ,Ečka “AD. Samples of carp were collected in April, June, September and October.

The protein content in fish sampled in September was significantly different from the protein content in fish sampled in April, June and October $(p<0.001),(17.48 \%, 17.27 \%, 18.28 \%$ and $17.26 \%$, respectively). The quantities of total lipids slightly increased $(2.25 \%, 2.37 \%, 3.02 \%$ and $4.72 \%$, respectively) with the increase of the fish weight (598 g, $874 \mathrm{~g}, 1439 \mathrm{~g}$ and $1984 \mathrm{~g}$, respectively), but significant increases occurred between September and October $(p<0.001)$. The moisture content decreased $(79.55 \%, 78.86 \%, 77.46 \%$ and $75.72 \%$, respectively). Principal Component Analysis (PCA) and Linear Discrimination Analysis (LDA) indicated that there were significant changes in the fatty acid composition of carp during growth. Starting from April to October the quantities of fatty acids were as follows: SFA (saturated fatty acids) - 28.47\%, 28.97\%, 24.86\% and 23.66\%, respectively; MUFA (monounsaturated fatty acids) $-38.57 \%, 40.52 \%, 41.68 \%$ and $42.43 \%$, respectively; PUFA (polyunsaturated fatty acids) $-32.53 \%, 30.49 \%, 31.53 \%$ and $32.55 \%$, respectively. The additional feeding of carp with the extruded feed influenced the increase in quantities of MUFA and n-6 PUFA (24.98\%, $22.86 \%, 26.96 \%$ and $27.99 \%$, respectively), and the decrease in quantities of the nutritionally important $n-3$ PUFA $(5.13 \%, 6.59 \%$, $4.57 \%$ and $4.57 \%$, respectively). The highest $n-3 / n-6$ ratio was obtained in June (0.30) and the lowest in October (0.16), indicating that the applied extruded feed was rich in n-6 and poor in n-3 PUFA. PCA and LDA have shown that significant changes in the fatty acid composition of carp during the breeding occured. Separation of the carp according to the sampling period was achieved by the LDA analysis, which is consistent with the type of ingested food.

Key words: carp, semi intensive farming, proximate composition, fatty acids, analysis of variance (ANOVA), Principal component analysis (PCA), Linear discrimination analysis (LDA).

\section{Introduction}

The limited resources of marine fish species and the growing demand for fish for human consumption have led to the expansion of aquaculture in many countries worldwide. Fatty acids (FA) which are provided by water resources play an important role in human nutrition (Ackman, 2000; Hunter and Roberts, 2000). Long-chain n-3 polyunsaturated fatty acids (PUFA) cannot be synthesized in the human body, and, therefore, they have to be ingested through diet (Alasalvar et al., 2002). There are numerous studies (Arts et al., 2001; Von Shacky, 2001; Mozaffarian et al., 2004; Givens et al., 2006; Sahena et al., 2009; Barcelo-Coblijn and Murphy, 2009) on the favourable effect of n-3 polyunsaturated fatty acids from fish on human health, confirming that increased fish consumption has a role in the prevention of coronary heart disease, especially myocardial infarction, arteriosclerosis, hypertension and other cardiovascular diseases. In addition to the prevention of coronary heart disease and hypertension reduction, the beneficial effect of n-3 PUFA is reflected in the prevention of the inflammatory (Moreno and Mitjavila, 2003) and autoimmune diseases (Zamaria, 2004 ), and cancer (Terry et al., 2004), diabetes (Nettleton and Katz, 2005), etc.

Cyprinidae fish family dominates world aquaculture, and the common carp is one of the oldest domesticated fish species for food (Balon, 2006). In Europe,

Acknowledgements: this work was supported by the projects TR 31075 and TR 31011, funded by the Ministry of Education, Science and Technological Development of the Republic of Serbia. 
particularly in the Central and Eastern Europe, cyprinids are one of the most important fish family in aquaculture production, and, among them, the common carp (Cyprinus carpio) is the most cultivated species. The dominant form of common carp production is the semi-intensive farming system, where the diet of the fish is based on a combination of natural food and supplementary feed (cereals, such as wheat, maize and barley). To improve and intensify the carp production cereals are replaced by extruded feed (Steffens and Wirth, 2007; Marković et al., 2009).

The meat composition and fatty acid profile of farmed carp are, to great extent, influenced by diet (Caballero et al., 2002; Valente et al., 2007; Ljubojević et al., 2012). Generally, under the same farming conditions, feed rich in $\mathrm{n}-3$ fatty acids greatly increases the n-3/n-6 PUFA ratio in the fish tissue (Robin and Skalli, 2007; Al-Souti et al., 2012). However, the lipid content and fatty acid composition of fish can differ within species depending on a variety of conditions, including gender, the state of the ecosystem inhabited by the fish, and the environmental conditions (Źmijewski et al., 2006; Vandeputte et al., 2008; Prato and Biandolino, 2012). Some other factors such as water temperature and its quality, the type and the availability of food, the season, age, and individual differences can influence these variations, as well (Rasoarahona et al., 2004; Guler et al., 2008; Trbović et al., 2009).

Considering the carp farming, literature data indicate that changes in the muscle mass of fish, which are reflected on its nutritional value, are caused by genetic factors, diet and environmental conditions (Gery et al., 1995; Fauconneau et al., 1995). It has been demonstrated providing to carp high-energy feed, in order to stimulate growth and to shorten the breeding time, mostly contributes to the increase in fat content, and protein content remains constant (Kaushik, 1995).

Fatty acid composition of farmed fish differs from the fatty acid composition of the fish from open waters, mainly because of diet, and fish from open waters is considered to contain larger amounts of n-3 PUFA. However, some research indicate that farmed fish contain higher amounts of n-3 PUFA, compared to the fish from open waters, when the fatty acids are expressed as $\mathrm{mg} / 100 \mathrm{~g}$ of the fish, instead as a weight percentage of the total fatty acids (Cahu et al. 2004).

Convenient climate conditions, and numerous rivers and rivers' accumulations in the lowlands of the country, contributed to a long-standing tradition in the cultivation of cyprinids, mainly carp, and in the creation of habits for carp consumption. Thus, freshwater fish belonging to the cyprinid family became economically and nutritionally important for Serbian population, and carp is nowadays one of the most cultivated fish species in the country. The increasing demands for higher productivity of carp farms, and for higher quality of the carp meat are contributing to improving the farming conditions. Carp is cultivated on farms with semi-intensive production systems, in which, except naturally occurring food, fish is additionally fed extruded feed or cereals.

Multivariate data analysis might correlate the fatty acid composition of the fish fed different diets to the fatty acid profiles of the feed (Barrado et al., 2003). The use of multivariate methods, such as principal component analysis (PCA) and linear discrimination analysis (LDA), enables a better understanding of the fatty acid composition of the carp meat according to the fish diet and summarizes the statistical correlation among fatty acids.

The aim of this study was to investigate and evaluate the proximate composition and fatty acid profiles of carp during rearing in semi-intensive farming conditions supplementary fed extruded feed. Data on the effect of supplementary diet on the lipid content and fatty acid composition of carp will be used to improve the nutritional value of carp meat.

\section{Materials and methods}

\section{Fish samples}

One-year old carp was submitted to trials from spring to autumn at the fish farm „Ečka“ $A D$, a farm with semi-intensive carp breeding system. The conditions on the farm were convenient for carp breeding, since the historical data indicate that an organized carp production started in the year 1891 (www.ribnjakecka.com). Carp samples were collected from spring to fall (April, June, September and October). Except naturally occurring food, according to the breeding season and to the fish farm productivity, fish were additionally fed extruded feed consisting of maize, soybean meal and fish meal. The feed contained $23.81 \%$ proteins and $6.97 \%$ lipids. Feed provided to the fish was as follows: in April $0.1 \%$ to $0.3 \%$, in May $0.3 \%$ to $1 \%$, in June $1 \%$ to $2 \%$, in July and August $3 \%$, in September 2\% to 3\%, with respect to fish biomass and depending on the water temperature, its saturation with oxygen and on the amount of accessible natural food. The weight of each fish was determined in the laboratory, on a technical balance. The fish samples were kept at $-25^{\circ} \mathrm{C}$ until analyses. Before analysis, fish was left at room temperature for an hour to defrost partly, so that the skin, heads, tails, fins and intestines could be removed, and fish afterwards was 
filleted. Fish fillets were disintegrated in a CombiMax 600 blender (Braun GmbH, Kronberg, Germany). Determination of proximate composition was performed in triplicate, while fatty acid analyses in duplicate.

\section{Chemicals and standards}

The chemicals for proximate composition analysis were of analytical grade purity. The solvents for GC analysis were of GC-grade purity, obtained from Merck (Darmstadt, Germany) and Sigma-Aldrich (Munich, Germany). Following regular cleaning according to the standard laboratory procedure, all glassware was rinsed sequentially with acetone and hexane. Solvent blanks were checked whenever new lots of reagents were used. The reagent for derivatization of fatty acids, $0.25 \mathrm{M} \mathrm{TMSH}$ (trimethylsulphonium hydroxide) in methanol, grade for GC derivatization, was purchased from Fluka (Buchs, Switzerland). Heneicosanoic acid methyl ester (p.a. $\geq 99 \%$, Fluka, Buchs, Switzerland) was used as internal standard.

The standards used for determination of fatty acids (Supelco 37 comp. FAME mix, $10 \mathrm{mg} \mathrm{mL}^{-1}$ in $\mathrm{CH}_{2} \mathrm{Cl}_{2}$ ), analytical standard grade, were purchased from Supelco (Bellefonte, USA). Before gas chromatographic analysis all sample extracts were filtered through a $0.2 \mu \mathrm{m}$ nylon syringe filters (Nipro Europe N.V., Zaventem, Belgium).

\section{Proximate composition analysis}

The proximate composition of fish samples was determined using standard SRPS ISO methods. Protein content in fish filets $(\mathrm{N} \times 6.25)$ was determined by the Kjeldahl procedure on a Kjeltec Auto 1030 Analyzer (Tecator, Höganäs, Sweden). Moisture content was determined by drying of samples at $103 \pm 2^{\circ} \mathrm{C}$ to constant mass (SRPS ISO 1442:1998). Total fat content was determined by extraction of the weighted amount of fish flesh with petroleum ether $\left(30-50^{\circ} \mathrm{C}\right.$ b.p.) in a Soxhlet apparatus, after acid hydrolysis of the sample (SRPS ISO 1443:1992). The ash content in the sample was determined by dry ashing at $550 \pm 25^{\circ} \mathrm{C}$ (SRPS ISO 936:1999).

\section{GC analysis of fatty acid}

Total lipids were extracted from the fish fillets using accelerated solvent extraction (ASE 200, Dionex, Sunnyvale, CA, USA), as previously reported (Spirić et al., 2010). Fatty acid methyl esters (FAME) were prepared by transesterification using $0.25 \mathrm{M}$ TMSH (EN ISO 5509:2000). Prior to transesterification, $0.05 \mathrm{~mL}(10 \mathrm{mg} / \mathrm{mL})$ of heneicosanoic acid methyl ester solution was added as an internal standard.
Fatty acid methyl esters were determined by GC Shimadzu 2010 (Kyoto, Japan) equipped with a split/splitless injector, fused silica cyanopropyl HP88 column (length $100 \mathrm{~m}$, i.d. $0.25 \mathrm{~mm}$, film thickness $0.20 \mu \mathrm{m}, J \& \mathrm{~W}$ Scientific, Orangevale, CA, USA), flame ionization detector and work station. The injection volume was $1 \mu \mathrm{L}$, in the split ratio of 1:50. Nitrogen was used as carrier gas at flow rate of $1.33 \mathrm{~mL} \mathrm{~min}^{-1}$. The injector and detector temperatures were $250^{\circ} \mathrm{C}$ and $280^{\circ} \mathrm{C}$, respectively. Hydrogen and air were used as flame gases, at flow rates of $40 \mathrm{~mL} \mathrm{~min}^{-1}$ and $400 \mathrm{~mL} \mathrm{~min}^{-1}$, respectively. Nitrogen was used as a make-up gas at flow rate of $30 \mathrm{~mL}$ $\mathrm{min}^{-1}$. The programmed column oven temperature, starting at $125^{\circ} \mathrm{C}$ and ending at $230^{\circ} \mathrm{C}$, was applied. More detailed data on the operating conditions have been previously reported (Trbović et al., 2013). Total analysis time was $50.5 \mathrm{~min}$. Chromatographic peaks in the samples were identified by comparing their relative retention times to FAME peaks retention times in the Supelco 37 Component FAME mix standard. Chromatographic peak areas were corrected by response factors. Response factors were calculated by the ratios between the peak area of the individual fatty acid methyl ester and of the internal standard. Relative quantities of fatty acids were expressed as weight $\%$ of the total fatty acids. The signal to noise $(\mathrm{S} / \mathrm{N})$ ratio was used for the estimation of the limit of detection, LOD $(\mathrm{LOD}=3 \times \mathrm{S} / \mathrm{N})$ and of the limit of quantification, $\mathrm{LOQ}(\mathrm{LOQ}=10 \times \mathrm{S} / \mathrm{N})$.

\section{Statistical analysis}

Analysis of variance (ANOVA) with Tukey Kramer test was used to analyze the data at $\mathrm{P}=0.05$ level. Principal component analysis (PCA) and linear discrimination analysis (LDA) were performed using JMP 8.0.1 software (SAS Institute Inc. NC, USA).

\section{Results and discussion}

Data on the water temperature on the farm, and the average carp weight during rearing are presented in Table 1. A significant increase in the fish weight between June and September $(p<0.001)$, and September and October $(\mathrm{p}<0.001)$ was established. The significant increase in the carp weight was a consequence of the intensive feeding of fish during summer, when carp consumed large quantities of supplementary feed. The favourable environmental conditions in the aquatic environment contributed to the increase of fish biomass, as well. 
Table 1. Water temperature and carp weight during rearing

Tabela 1. Temperatura vode i masa šarana u toku uzgoja

\begin{tabular}{lcccc}
\hline & April $(\mathbf{n}=\mathbf{6})$ & June $(\mathbf{n}=7)$ & September $(\mathbf{n}=7)$ & October $(\mathbf{n}=\mathbf{8})$ \\
\hline $\begin{array}{l}\text { Water temperature, }{ }^{\circ} \mathrm{C} / \\
\text { Temperatura vode, }{ }^{\circ} \mathrm{C}\end{array}$ & 14 & 22 & 20 & 6 \\
$\begin{array}{l}\text { Carp weight, g/ } \\
\text { Masa šarana, g }\end{array}$ & $598 \pm 162^{\mathrm{C}}$ & $874 \pm 142^{\mathrm{C}}$ & $1439 \pm 173^{\mathrm{B}}$ & $1984 \pm 322^{\mathrm{A}}$ \\
\hline
\end{tabular}

$\mathrm{n}$ - number of samples; $\mathrm{A}, \mathrm{B}, \mathrm{C}-$ Values in the same row followed by the same letters do not differ significantly $(\mathrm{P}>0.05) /$ $\mathrm{n}$ - broj uzoraka; ${ }^{\mathrm{A}, \mathrm{B}, \mathrm{C}}$ - Vrednosti $\mathrm{u}$ istom redu sa istim slovnim oznakama se značajno ne razlikuju $(\mathrm{P}>0.05)$

Data for the proximate composition of carp during rearing are presented in Table 2.

The protein content in fish sampled in September was significantly different from the protein content in fish sampled in April, June and October $(p<0.001)$. The total lipids slightly increased with the increasing size of the fish, but a significant increase occurred from September to October $(p<0.001)$. On the contrary, the moisture content decreased $(p<0.001)$. Generally, the total lipids in the carp meat were in the range from $2.25-4.72 \%$, what classifies the carp from aquaculture in a low fatty fish (Huss, 1995). Ash content was significantly different in carp sampled in June from the carp sampled in September $(p<0.01)$ and October $(p<0.01)$. As ash content is endogenously regulated, this might be a consequence of biological changes during the fish growth (Shearer, 1994).

Fatty acid composition ( $\%$ of total fatty acids) of carp during rearing is presented in Table 3 .
From the presented data, it is noticable that the levels of MUFA significantly increased during fish grow, while the levels of SFA decreased. The share of total PUFA in the fillets did not change significantly during carp rearing ( $p>0.05)$.

ANOVA test indicated that between June and September the content of n-6 PUFA significantly increased $(p<0.01)$, while the content of $n-3$ PUFA decreased $(p<0.01)$, what is associated with an increased feed intake during summer period, The increase in n- 6 PUFA led to a reduction in the n-3/n- 6 ratio, and, thus, to the reduction of the quality of the fish. The $n-3 / n-6$ ratio was the highest in June $(0.30)$, and the lowest in October $(0.16)$, indicating the quality of the carp feed, which was rich in n-6 and poor in n-3 PUFA, in October. Henderson and Tocher (1987) have reported n-3/n- 6 values of 0.5-3.8 for freshwater fish.

Changes in the fatty acid profiles in carp during rearing are better visualized by PCA (Figure 1 and 2).

Table 2. Proximate composition of carp during rearing

Tabela 2. Hemijski sastav šarana u toku uzgoja

\section{Chemical parameters/ \\ Hemijski parametri}

Proteins, $\% /$ Proteini, $\%$

Moisture, \%/Vlaga, \%

Total lipids,\%/Ukupni lipidi,\%

Ash, $\% /$ Pepeo, $\%$

$$
\text { April }(n=6) \quad \text { June }(n=7)
$$

September $(\mathbf{n}=7)$

$18.28 \pm 0.29^{\mathrm{A}}$

$17.26 \pm 0.30^{\mathrm{B}}$

$17.27 \pm 0.47^{\mathrm{B}}$

$18.28+0.29 \mathrm{~A}$

$17.26 \pm 0.30^{\mathrm{B}}$

$\mathrm{n}$ - number of samples; A, B, C - Values in the same row followed by the same letters do not differ significantly $(\mathrm{p}>0.05)$

$\mathrm{n}$ - broj uzoraka; ${ }^{\mathrm{A}, \mathrm{B}, \mathrm{C}}-$ Vrednosti u istom redu sa istim slovnim oznakama se značajno ne razlikuju ( $\mathrm{p}>0.05$ ) 
Table 3. Fatty acid composition ( $\%$ of total fatty acids) of carp during rearing Tabela 3. Sastav masnih kiselina (\% od ukupnih masnih kiselina) šarana u toku uzgoja

\begin{tabular}{|c|c|c|c|c|}
\hline $\begin{array}{l}\text { Fatty acids/ } \\
\text { Masne kiseline }\end{array}$ & April $(n=6)$ & June $(n=7)$ & September $(n=7)$ & October $(n=8)$ \\
\hline $14: 0$ & $1.23 \pm 0.24^{\mathrm{A}}$ & $1.21 \pm 0.15^{\mathrm{A}}$ & $0.82 \pm 0.05^{\mathrm{B}}$ & $0.84 \pm 0.06^{\mathrm{B}}$ \\
\hline $15: 0$ & $0.34 \pm 0.22^{\mathrm{A}}$ & $0.33 \pm 0.16^{\mathrm{A}}$ & $0.22 \pm 0.03^{\mathrm{A}}$ & $0.18 \pm 0.04^{\mathrm{A}}$ \\
\hline $16: 0$ & $19.89 \pm 2.41^{\mathrm{AB}}$ & $20.86 \pm 1.13^{\mathrm{A}}$ & $18.28 \pm 0.89^{\mathrm{BC}}$ & $17.80 \pm 0.76^{\mathrm{C}}$ \\
\hline $16: 1$ & $6.32 \pm 1.13^{\mathrm{A}}$ & $5.43 \pm 1.32^{\mathrm{AB}}$ & $3.97 \pm 0.43^{\mathrm{B}}$ & $5.01 \pm 0.83^{\mathrm{AB}}$ \\
\hline $17: 0$ & $0.64 \pm 0.31^{\mathrm{A}}$ & $0.61 \pm 0.09^{\mathrm{A}}$ & $0.39 \pm 0.04^{\mathrm{B}}$ & $0.34 \pm 0.08^{\mathrm{B}}$ \\
\hline $18: 0$ & $6.37 \pm 1.04^{\mathrm{A}}$ & $5.95 \pm 0.52^{\mathrm{A}}$ & $5.15 \pm 0.44^{\mathrm{B}}$ & $4.48 \pm 0.28^{\mathrm{C}}$ \\
\hline $18: 1 n-9$ & $26.68 \pm 3.20^{\mathrm{B}}$ & $30.74 \pm 1.58^{\mathrm{AB}}$ & $33.55 \pm 2.59^{\mathrm{A}}$ & $33.09 \pm 2.46^{\mathrm{A}}$ \\
\hline $18: 1 \mathrm{n}-7$ & $3.93 \pm 1.19^{\mathrm{A}}$ & $2.84 \pm 0.32^{\mathrm{B}}$ & $2.42 \pm 0.08^{\mathrm{B}}$ & $2.57 \pm 0.18^{\mathrm{B}}$ \\
\hline $18: 2 n-6$ & $22.30 \pm 4.19^{\mathrm{B}}$ & $21.45 \pm 3.24^{\mathrm{B}}$ & $25.04 \pm 0.62^{\mathrm{AB}}$ & $26.09 \pm 1.81^{\mathrm{A}}$ \\
\hline $18: 3 n-6$ & $0 \pm 0^{\mathrm{C}}$ & $0.12 \pm 0.20^{\mathrm{CB}}$ & $0.25 \pm 0.04^{\mathrm{B}}$ & $0.34 \pm 0.05^{\mathrm{A}}$ \\
\hline $18: 3 n-3$ & $2.24 \pm 0.52^{\mathrm{B}}$ & $3.86 \pm 0.54^{\mathrm{A}}$ & $2.12 \pm 0.34^{\mathrm{B}}$ & $2.23 \pm 0.27^{\mathrm{B}}$ \\
\hline $20: 1$ & $1.74 \pm 0.07^{\mathrm{A}}$ & $1.51 \pm 0.08^{\mathrm{B}}$ & $1.70 \pm 0.24^{\mathrm{AB}}$ & $1.76 \pm 0.24^{\mathrm{A}}$ \\
\hline $20: 2$ & $1.02 \pm 0.13^{\mathrm{A}}$ & $0.66 \pm 0.12^{\mathrm{B}}$ & $0.81 \pm 0.13^{\mathrm{B}}$ & $0.68 \pm 0.09^{\mathrm{B}}$ \\
\hline $20: 3 n-6$ & $1.41 \pm 0.49^{\mathrm{A}}$ & $0.64 \pm 0.08^{\mathrm{B}}$ & $0.86 \pm 0.44^{\mathrm{B}}$ & $0.85 \pm 0.41^{\mathrm{B}}$ \\
\hline $20: 3 n-3$ & $0.50 \pm 0.09^{\mathrm{AB}}$ & $0.50 \pm 0.10^{\mathrm{B}}$ & $0.70 \pm 0.22^{\mathrm{A}}$ & $0.47 \pm 0.11^{\mathrm{B}}$ \\
\hline $22: 1+20: 4$ & $2.41 \pm 0.19^{\mathrm{A}}$ & $1.04 \pm 0.28^{\mathrm{B}}$ & $1.25 \pm 0.14^{\mathrm{B}}$ & $1.35 \pm 0.28^{\mathrm{B}}$ \\
\hline $20: 5 n-3$ & $0.89 \pm 0.26^{\mathrm{A}}$ & $0.96 \pm 0.26^{\mathrm{A}}$ & $0.52 \pm 0.16^{\mathrm{B}}$ & $0.58 \pm 0.13^{\text {В }}$ \\
\hline $22: 5 n-3$ & $0.52 \pm 0.12^{\mathrm{A}}$ & $0.46 \pm 0.13^{\mathrm{A}}$ & $0.29 \pm 0.09^{\mathrm{B}}$ & $0.28 \pm 0.07^{\mathrm{B}}$ \\
\hline $22: 6 n-3$ & $1.21 \pm 0.29^{\mathrm{A}}$ & $0.81 \pm 0.20^{\mathrm{A}}$ & $0.94 \pm 0.22^{\mathrm{A}}$ & $1.01 \pm 0.27^{\mathrm{A}}$ \\
\hline SFA & $28.47 \pm 3.92^{\mathrm{A}}$ & $28.97 \pm 1.25^{\mathrm{A}}$ & $24.86 \pm 1.03^{\mathrm{B}}$ & $23.66 \pm 0.80^{\mathrm{B}}$ \\
\hline MUFA & $38.57 \pm 2.03^{\mathrm{B}}$ & $40.52 \pm 2.48^{\mathrm{AB}}$ & $41.68 \pm 2.59^{\mathrm{A}}$ & $42.43 \pm 2.93^{\mathrm{A}}$ \\
\hline PUFA & $32.52 \pm 3.38^{\mathrm{A}}$ & $30.49 \pm 3.12^{\mathrm{A}}$ & $31.53 \pm 1.91^{\mathrm{A}}$ & $32.55 \pm 2.37^{\mathrm{A}}$ \\
\hline$n-3$ & $5.13 \pm 0.90^{\mathrm{B}}$ & $6.59 \pm 0.89^{\mathrm{A}}$ & $4.57 \pm 0.59^{\mathrm{B}}$ & $4.57 \pm 0.66^{\mathrm{B}}$ \\
\hline$n-6$ & $24.98 \pm 3.83^{\mathrm{AB}}$ & $22.86 \pm 3.24^{\mathrm{B}}$ & $26.96 \pm 1.75^{\mathrm{A}}$ & $27.99 \pm 1.91^{\mathrm{A}}$ \\
\hline$n-3 / n-6$ & $0.21 \pm 0.06^{\mathrm{B}}$ & $0.29 \pm 0.07^{\mathrm{A}}$ & $0.17 \pm 0.02^{\mathrm{BC}}$ & $0.16 \pm 0.02^{\mathrm{C}}$ \\
\hline
\end{tabular}

$\mathrm{n}$ - number of samples; ${ }^{\mathrm{A}, \mathrm{B}, \mathrm{C}}$ - Values in the same row followed by the same letters do not differ significantly $(\mathrm{p}>0.05)$ $\mathrm{n}$ - broj uzoraka; ${ }^{\mathrm{A}, \mathrm{B}, \mathrm{C}}$ - Vrednosti u istom redu sa istim slovnim oznakama se značajno ne razlikuju ( $\left.\mathrm{p}>0.05\right)$

PCA of the fatty acid profiles, taking carp weight and lipid content as variables, resulted in two principal components model describing $60.3 \%$ of the total data variability. In particular, PC1 explained $42.8 \%$ of the variability and PC2 explained about $17.5 \%$. The score plot of the first two principal components (Figure 1) indicated to the grouping of carps during growth according to the months of sampling.

Considering groups of FA and the most important fatty acids, such as oleic, 18:1n-9; linoleic, 18:2n-6; linolenic acid, 18:3n-3; EPA, 20:5n-3;
DPA, 22:5n-3 and DHA, 22:6n-3, the PCA clearly differentiated carps according to the period of sampling.

As it can be seen from the Figure 2, oleic acid contributed to the great extent to the variability on the positive part of the PC1. High positive correlation of oleic acid with carp weight and total lipids $(r>0.6$; $\mathrm{p}<0.0001$ ) indicated that the total lipids and the content of oleic acid increased with the increase of carp weight. Linoleic acid that contributed to the positive part of the PC2 enabled to distinguish carp in September and October with higher amounts of this fatty acid. 


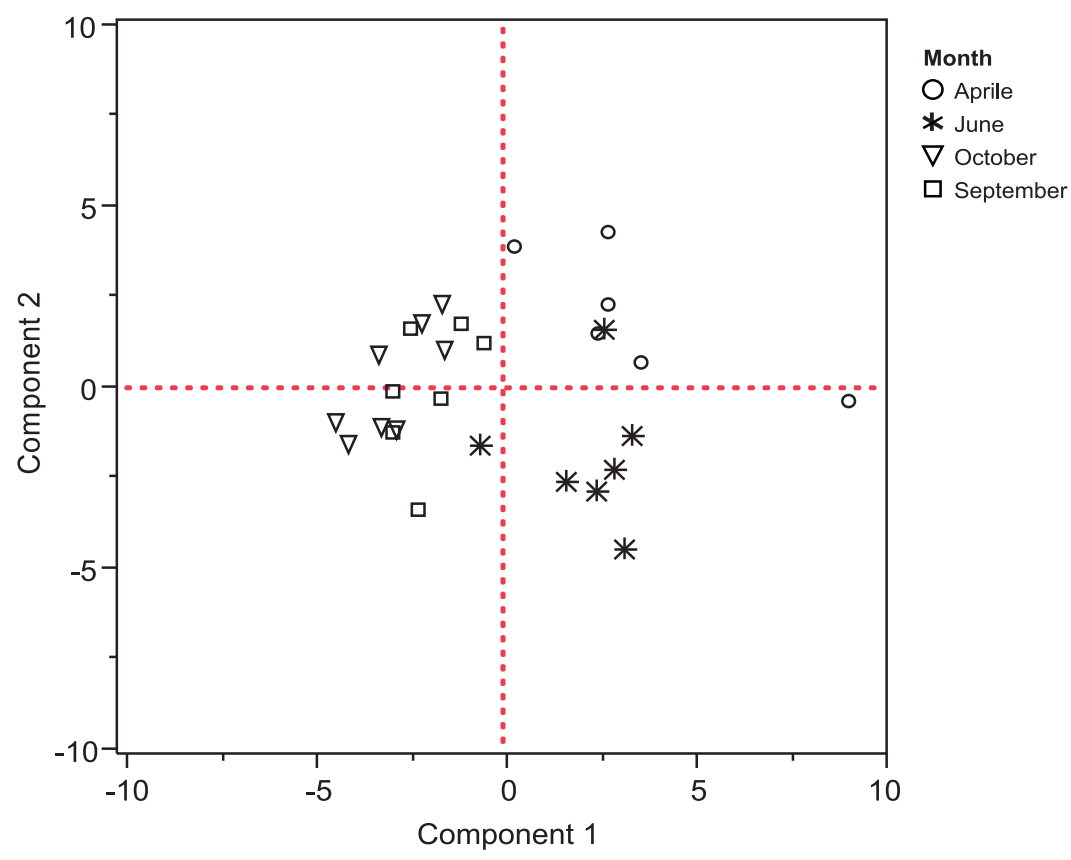

Figure 1. Principal component analysis score plot of the fatty acid profiles of carps during rearing Slika 1. Vrednosti skorova dobijenih analizom glavnih komponenti za sastav masnih kiselina šarana u toku uzgoja

On the negative part of the PC1, DPA, EPA and linolenic acid correspond to carp which contained higher quantities of these fatty acids in April and June. Carp can adjust the fatty acid metabolism to the prevailing temperature in such a way that increases in the temperature gives rise to the increased metabolism of saturated fatty acids (Tocher, 2003).
This is, probably, the reason why SFA were presented in June in higher quantities, when temperature was the highest. The presence of the linolenic acid and of the long-chain PUFA (EPA, DPA) in carps in April and June could be a consequence of the higher intake of natural food. The natural food, represented by plankton and benthos, is a source rich in linolenic

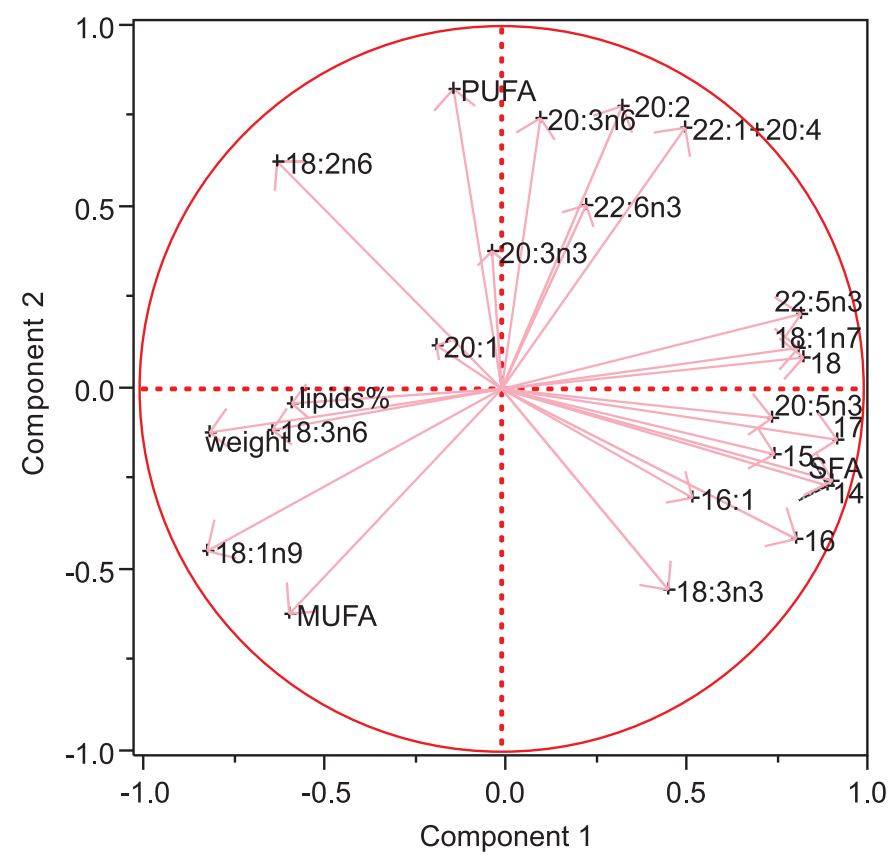

Figure 2. Principal component analysis loading plot of the fatty acid profiles of carps during rearing Slika 2. Projekcija vektora dobijenih analizom glavnih komponenti za sastav masnih kiselina šarana u toku uzgoja 


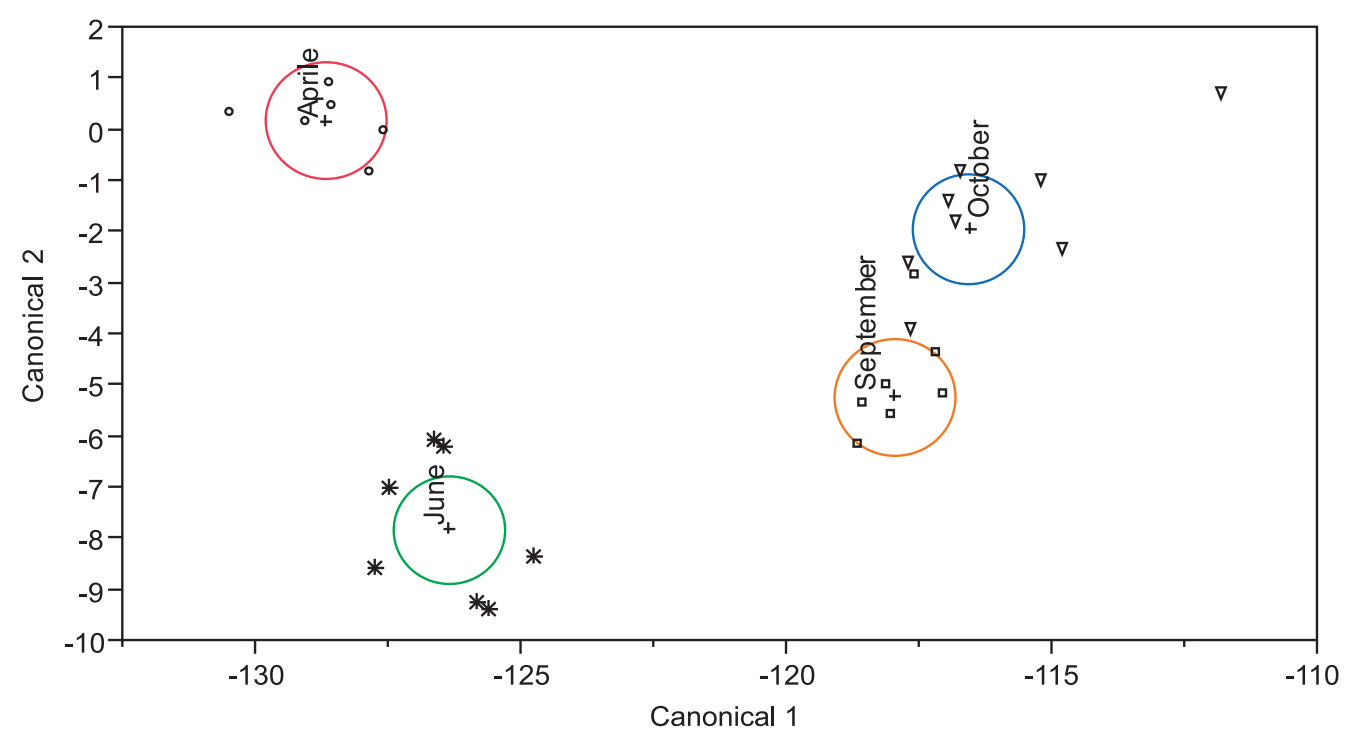

Figure 3. Canonical plot of the fatty acid profiles of carps during rearing

Slika 3. Kanonični prikaz sastava masnih kiselina šarana u toku uzgoja

acid and EPA (Domaizon et al., 2000; Bogut et al., 2007; Živic et al., 2011), but poor in DHA. Bell et al. (1994) have reported that DHA in freshwater invertebrates was present in small amounts. The availability of natural food in April and June, probably, caused an increase in the content of n-3 fatty acids in carp, what consequently resulted in a better quality of the fish meat.

The separation of carps during rearing might be improved by the linear discrimination analysis. From the data presented in Figure 3, a clear differentiation of carps in four groups is noticable, according to the months of sampling. The grouping was very satisfactory, and allowed $96 \%$ of the fish to be correctly grouped. Out of the 28 tested samples, 27 were classified according to the months of sampling.

LDA demonstrated that the first discriminant eigenvalue (27.7) explained $67 \%$ of the total variance and the second eigenvalue (11.7) explained $28 \%$ of the total variance. The established Wilks value was equal to $0.0009(\mathrm{p}<0.0001)$. By canonical correlation, the first and the second discriminant functions were established to be 0.982 and 0.960 , respectively.

As the distances between the points on the canonical plot are shorter, the differences in the FA profiles of the fish samples are smaller. As it can be seen, fish in April and June are distant one from the other and far from September and October, which is in correlation to the type of the ingested food in that period. The shortest distance, e.g. the greatest similarity in the FA profiles, was observed between carps in September and October, due to the reduction of natural food on the farm and to the higher intake of the supplementary feed.

\section{Conclusion}

The obtained data indicate that the protein content in fish sampled in September was significantly different from the protein content in fish sampled in April, June and October $(\mathrm{p}<0.001)$. The quantities of the total lipids slightly increased with the increase of the fish weight. But, significant increase occurred from September to October $(p<0.001)$. On the contrary, the moisture content decreased.

Based on the PCA and LDA, it can be concluded that there were significant changes in the fatty acid composition of carp during the investigating period of growth. Except supplementary feed, the availability of natural food on the carp farm influenced the fatty acid composition of carp during rearing. However, the additional feeding of carp with extruded feed influenced the increase in quantities of MUFA and n-6 PUFA, and the decrease in the quantities of nutritionally important $n-3$ PUFA. The highest $n-3 / n-6$ ratio was obtained in June (0.30), and the lowest in October (0.16), indicating that the applied extruded feed was rich in $n-6$ and poor in n-3 PUFA. Analysis of the fatty acid composition in combination with multivariate analysis is a powerful tool in differentiation of carp during rearing according to the food available on the farm, and to the offered supplementary feed, as well. Based on this analysis, it can be concluded that the quality of supplementary feed has to be improved in order to achieve better nutritional quality of the final product. 


\section{References}

Ackman R. G., 2000. Nutritional composition of fats in seafoods. Progress in Food and Nutrition Science, 13, 161-241.

Alasalvar C., Taylor K. D. A., Zubcov, E., Shahidi, F., Alexis, M., 2002. Differentiation of cultured and wild sea bass (Dicentrarchus labrax): total lipid content, fatty acid and trace mineral composition. Food Chemistry, 79, 145-150.

Al-Souti A., Al-Sabahi J., Soussi B., Goddard S., 2012. il-enriched diets on growth, feed conversion and fatty acid content of red hybrid tilapia, Oreochromis sp. Food Chemistry, 133, 723-727.

Arts M. T., Ackman R. G., Holub B. J., 2001. "Essential fatty acids" in aquatic ecosystems: a crucial link between diet and human health and evolution. Canadian Jorunal of Fisheries and Aquatic Sciences, 58, 122-137.

Balon E. K., 2006. The oldest domesticated fishes, and the consequences of an epigenetic dichotomy in fish culture. Journal of Ichthyology and Aquatic Biology, 11, 47-86.

Barcelo-Coblijn G., Murphy E. J., 2009. Alpha-linolenic acid and its conversion to longer chain n-3 fatty acids: Benefits for human health and a role in maintaining tissue n-3 fatty acid levels. Progress in Lipid Research, 48, 355-374.

Barrado E., Jiménez F., Prieto F., Nuevo C., 2003. The use of fatty-acid profiles of the lipids of the rainbow trout (Onchorynchus mykiss) to differentiate tissue and dietary feed. Food Chemistry 81, 13-20.

Bell J. G., Ghioni, C., Sargent J. R., 1994. Fatty acid compositions of 10 freshwater invertebrates which are natural food organisms of Atlantic salmon parr (Salmo salar): a comparison with commercial diets. Aquaculture, 128, 301-313.

Bogut I., Has - Schön E., Adámek Z., Rajković V., Galović, D., 2007. Chironomus plumosus larvae - a suitable nutrient for freshwater farmed fish. Agriculture, 13, 1-5.

Caballero M. J., Obach A., Rosenlund G., Montero D., Gisvold M., Izquierdo M. S., 2002. Impact of different dietary lipid sources on growth, lipid digestability, tissue fatty acid composition and histology of rainbown trout, Oncorhynchus mykiss. Agriculture, 214, 253-271.

Cahu C., Salen P., de Lorgeril M., 2004. Farmed and wild fish in the prevention of cardiovasular diseases: Assessing possible differences in lipid nutritional values. Nutrition Metabolism and Cardiovascular Diseases, 14, 34-41.

Domaizon I., Desvilettes C., Debroas, D., Bourdier G., 2000. Influence of zooplankton and phytoplankton on the fatty acid composition of digesta and tissue lipids of silver carp: mesocosm experiment. Journal of Fish Biology, 57, 417-432.

Fauconneau B., Alami-Durante H., Laroche M., Marcel J., Vallot D., 1995. Growth and meat quality relations in carp. Aquaculture, 129, 265-297.

Geri G., Poli B. M., Gualtieri M., Lupi P., Parisi G., 1995. Body traits and chemical composition of muscle in the common carp (Cyprinus carpio L.) as influenced by age and rearing environment. Aquaculture,129, 329-333.

Givens D. I., Kliem K. E., Gibbs R. A., 2006. The role of meat as a source of n-3 polyunsaturated fatty acids in the human diet. Meat Science, 74, 209-218.

Guler G.O., Kiztanir B., Aktumsek A., Citil O.B., Ozparlak H., 2008. Determination of the seasonal changes on total fatty acid composition and n-3/n-6 ratios of carp (Cyprinus carpio L.) muscle lipids in Beysehir Lake (Turkey). Food Chemistry, 108, 689-694.
Henderson R. J., Tocher D. R., 1987. The lipid composition and biochemistry of freshwater fish. Progress in Lipid Research, 26, 281-347.

Hunter B. J., Roberts D. C. K., 2000. Potential impakt of the fat composition of farmed fish on human health. Nutrition Research, 20, 1047-1058.

Huss H. H., 1995. Quality and quality changes in fresh fish. FAO Fisheries Technical Paper - 348. Food and Agriculture Organization of the United Nations Rome, 1995.

Kaushik S. J., 1995. Nutrient requirements, supply and utilization in the context of carp culture. Aquaculture, 129, 225-241.

Ljubojević D., Ćirković M., Novakov N., Babić J., Lujić J., Marković T., 2012. Faktori koji utiču na randman šaranskih riba. Tehnologija mesa, 53, 1, 14-19.

Marković Z., Poleksić V., Živić I., Stanković M., Ćuk D., Spasić M., Dulić Z., Rašković B., Ćirić M., Bošković D., Vukojević D., 2009. State of the art of fishery in Serbia. Proceedings of the IV International Conference „Fishery“. Publisher: Faculty of Agriculture University of Belgrade, Serbia, 30-38.

Moreno J. J., Mitjavila M. T., 2003. The degree of unsaturation of dietary fatty acids and the development of atherosclerosis. Journal of Nutritional Biochemistry, 14, 182-195.

Mozaffarian D., Psaty B. M., Rimm E. B., Lemaitre R. N., Burke G. L., Lyles M. F., Lefkowitz D., Siscovick D. S., 2004. Fish intake and risk of incident atrial fibrillation. Circulation, 110, 368-373.

Nettleton J. A., Katz R., 2005. n-3 long-chain polyunsaturated fatty acids in type 2 diabetes: a review. Journal of the American Dietetic Association, 105, 428-440.

Prato E., Biandolino F., 2012. Total lipid content and fatty acid composition of commercially important fish species from the Mediterranean, Mar Grande Sea. Food Chemistry 131, 1233-1239.

Rasoarahona J. R. E., Barnathan G., Bianchini J. P., Gaydou E. M., 2004. Annual Evolution of Fatty Acid Profile from Muscle Lipids of the Common Carp (Cyprinus carpio) in Madagascar Inland Waters. Journal of Agricultural and Food Chemistry, 52, 7339-7344.

Robin J. H., Skalli A., 2007. Incorporation of dietary fatty acid in European sea bass (Dicentrarchus labrax) - A methodological approach evidencing losses of highly unsaturated fatty acids. Aquaculture, 263, 227-237.

Sahena F., Zaidul I. S. M., Jinap S., Saari N., Jahurul H. A., Abbas K. A.,Norulaini N. A., 2009. PUFAs in fish: extraction, fractionation, importance in health. Comprehensive Reviews in food science and food safety, 8, 59-74.

Shearer K. D., 1994. Factors affecting the proximate composition of cultured fishes with emphasis on salmonids. Aquaculture, 119, 63-88.

Spirić A., Trbović D., Vranić D., Djinović J., Petronijević R., Matekalo-Sverak V., 2010. Statistical evaluation of fatty acid profile and cholesterol content in fish (common carp) lipids obtained by different sample preparation procedures. Analytica Chemica Acta, 672, 66-71.

Steffens W., Wirth M., 2007. Influence of nutrition on the lipid quality of pond fish: common carp (Cyprinus carpio) and tench (Tinca tinca). Aquaculture International, 15, 313-319. 
Terry P. D., Terry J. B., Rohan T. E., 2004. Long-chain (n-3) fatty acid intake and risk of cancers of the breast and the prostate recent epidemiological studies, biological mechanisms, and directions for future research. Journal of $\mathrm{Nu}$ trition, 134, 3412S-3420S.

Tocher D.R., 2003. Metabolism and functions of lipids and fatty acids in teleost fish. Review in Fisheries Science, 11, 2, 107-184.

Trbović D., Vranić D., Đinović J., Borović B., Spiric D., Babić, J., Spirić A., 2009. Fatty acid profile and cholesterol content in filets of one year old common carp ( $C y$ prinus carpio) during growth. Tehnologija mesa 5-6, 276-286.

Trbovic D., Marković Z., Milojković-Opsenica D., Petronijević R., Spirić D., Đinović-Stojanović J., Spirić A., 2013. Influence on diet on proximate composition and fatty acid profile in common carp (Cyprinus carpio). Journal of Food Composition and Analysis, http://dx.doi.org/10.1016/j.jfca2013.04.002.

Valente L. M. P., Bandarra N. M., Figueiredo-Silva A. C., Rema P., Vaz-Pires P., Martins S., Prates J. A. M., Nunes M. L., 2007. Conjugated linoleic acid in diets for large-size rainbow trout (Oncorhynchus mykiss): effects on growth, chemical composition and sensory attributes. British Journal of Nutrition, 97, 289-297.
Vandeputte M., Kocour M., Mauger S., Rodina M., Launay A., Gela D., Dupont-Nivet M., Hulak M., Linhard O., 2008. Genetic variation for growth at one and two summers of age in the common carp (Cyprinus carpio L.): Heritability estimates and response to selection. Aquaculture, 277, 7-13.

Von Shacky C., 2001. Clinical trials, not n-6 to n-3 ratios, will resolve whether fatty acids prevent coronary heart disease. European Journal of Lipid Science and Technology, 103, 423-427.

Zamaria N., 2004. Alteration of polyunsaturated fatty acid status and metabolism in health and disease. Reproduction Nutrition Development, 44, 273-282.

Żmijewski T., Kujawa R., Jankowska B., Kwiatkowska A., Mamcarz A., 2006. Slaughter yield, proximate and fatty acid composition and sensory properties of rapfen (Aspius aspius ) with tissue of bream (Abramis brama $\mathrm{L})$ and pike (Esox lucius L). Journal of Food Composition and Analysis, 19, 176-181.

Živić I., Trbović, D. Živić M., Bjelanović K., Stanković M., Vukojević D., Marković Z. 2011. Chironomus Plumosus (Diptera, Insecta) larvae as a source of essential fatty acids in feed of carp fry. V International Conference "Aquaculture \& Fishery", Institute of Animal Science, Faculty of Agriculture, Belgrade-Zemun, Serbia, June 1-3. Conference Proceedings, 497-503.

\title{
Promene hemijskog i masnokiselinskog sastava mesa šarana u toku poluintenzivnog uzgoja
}

\author{
Trbović Dejana, Marković Zoran, Petronijević Radivoj, Milijašević Milan, Spirić Danka, Vranić Danijela, \\ Spirić Aurelija
}

R e z i m e: Cilj ovog rada bio je ispitivanje osnovnog hemijskog i masnokiselinskog sastava šarana (Cyprinus carpio) u toku uzgoja u poluintenzivnom sistemu uz prihranjivanje ribe ekstrudiranom hranom, kao i statistička evaluacija dobijenih rezultata. Eksperiment je realizovan od proleća do jeseni, na ribarskom gazdinstvu „Ečka “AD, a korišćen je dvogodišnji šaran u nasadu za dvogodišnji. Uzorci šarana su uzimani u toku aprila, juna, septembra i oktobra meseca.

Sadržaj proteina u šaranu koji je uzorkovan u septembru značajno se razlikovao od sadržaja proteina u šaranu koji je uzorkovan u aprilu, junu i oktobru (p<0,001), (17,48\%, 17,27\%, 18,28\% i 17,26\%, respektivno). Količine ukupnih lipida su blago rasle (2,25\%, 2,37\%, 3,02\% i 4,72\%, respektivno) sa povećanjem mase ribe (598 g, $874 \mathrm{~g}, 1439 \mathrm{~g} i 1984 \mathrm{~g}$, respektivno), a između septembra $i$ oktobra došlo je do značajnog povećanja ukupnih lipida (p<0,001). Sadržaj vlage se smanjivao (79,55\%, 78,86\%, 77,46\% i 75,72\%, respektivno). Analiza glavnih komponenti (Principal Component Analysis, PCA) i diskriminaciona linearna analiza (Linear Discrimination Analysis, LDA) ukazuju da je u toku perioda rasta ribe došlo do značajnih promena u sastavu masnih kiselina. U periodu istraživanja, od aprila do oktobra, količine masnih kiselina su bile sledeće: ZMK (zasićene masne kiseline) - 28,47\%, 28,97\%, 24,86\% i 23,66\%, respektivno; MNMK (mononezasićene masne kiseline) - 38,57\%, 40,52\%, 41,68\% i 42,43\%, respektivno, PNMK (polinezasićene masne kiseline) - 32,.53\%, 30,49, 31,53\% i 32,55\%\%, respektivno. Prihranjivanje šarana ekstrudiranom hranom uticalo je na porast količina MNMK i n-6 PNMK (24,98\%, 22,86\%, 26,96\% i 27,99\%, respektivno), kao i na smanjenje količina nutritivno važnih n-3 PNMK (5,13, 6,59\%\%, 4,57\% i 4,57\%, respektivno). Najveći odnos n-3/n-6 masnih kiselina dobijen je u junu (0,30), a najmanji u oktobru $(0,16)$, što ukazuje da je ekstrudirana hrana koja je na ribnjaku korišćena bila bogata sa n-6 i siromašna sa n-3 PNMK. PCA i LDA su pokazale da je došlo do značajnih promena u sastavu masnih kiselina šarana tokom uzgoja. LDA analizom postignuto je razdvajanje šarana prema periodu uzorkovanja, a što je u korelaciji sa vrstom unete hrane.

Ključne reči: šaran, poluintenzivni uzgoj, osnovni hemijski sastav, masne kiseline, analiza varijansi (ANOVA), analiza glavnih komponenti (PCA), linearna diskriminaciona analiza (LDA).

Paper received: 9.08 .2013 .

Paper accepted: 30.08 .2013 